Al-Khwarizmi Engineering Journal,Vol. 13, No. 1, P.P. 26- 41 (2017)

Al-Khwarizmi

Engineering

Journal

\title{
Improvement of Dynamic Buckling Behavior of Intermediate Aluminized Stainless Steel Columns
}

\author{
Ahmed Naif Al-Khazraji* \\ Samir Ali Al-Rabii** \\ Hameed Shamkhi Al-Khazaali *** \\ ****Department of Mechanical Engineering / University of Technology/Baghdad \\ ***Department of Machines and Equipment / Institute of Technology / Middle Technical University / Baghdad \\ *Email: dr_ahmed53@yahoo.com \\ **Email: alrabiee2002@yahoo.com \\ ***Email: hameedshamkhi@yahoo.com
}

(Received 20 October 2015; accepted 8 August 2016)

hittps://doi.org/10.22153/kej.2017.08.003

\begin{abstract}
This paper experimentally investigated the dynamic buckling behavior of AISI 303 stainless steel aluminized and as received intermediate columns. Twenty seven specimens without aluminizing (type 1) and 75 specimens with hot-dip aluminizing at different aluminizing conditions of dipping temperature and dipping time (type 2), were tested under dynamic compression loading (compression and torsion), dynamic bending loading (bending and torsion), and under dynamic combined loading (compression, bending, and torsion) by using a rotating buckling test machine. The experimental results werecompared with tangent modulus theory, reduced modulus theory, and Perry Robertson interaction formula. Reduced modulus was formulated to circular cross-section for the specimens of type (1).The experimental results obtained showed an advantageous influence of hot-dip aluminizing treatment on the dynamic buckling behavior of AISI 303 stainless steel intermediate columns. The improvements based on the average value of critical stress were $19.4 \%$ for intermediate columns type (2) compared with columns type (1) under dynamic compression loading, $8.7 \%$ for intermediate columns type (2) compared with columns type (1) under dynamic bending loading, and $16.5 \%$ for intermediate columns type (2) compared with columns type (1) under dynamic combined loading.
\end{abstract}

Keywords: Dynamic buckling, hot-dip Aluminizing, intermediate columns, AISI 303 stainless steel.

\section{Introduction}

Buckling may occur when there were compressive internal forces in the structure member. In fact, while tensile forces may only do work if the material deforms or rupture, for the case of compression there is a third possibility buckling- which consists of a lateral deflection of the material, in relation to direction of actuation of the compressive forces [1]. The phenomenon of buckling is not limited to columns. Buckling can occur in beams, plates, shells, and other structural members under a variety of loading conditions $[2$, 3]. The buckling behavior of steel columns considers one of the important phenomenon that had been studied and analyzed from a long time. A series of experimentally tests are carried on cold formed austenitic stainless steel square, rectangular, and circular hollow section members to examine the buckling behavior of columns and beams under effect of gradually increased single and combined loads (compression, bending, and compression-bending) with two types of ends conditions pin-ends and fixed-ends [4]. The buckling of solid and hollow CK35 and CK45 alloy steel columns under combined dynamic loading has been studied experimentally and the obtained results showed that the failure resistance of the columns depends on the type of crosssection and initial deflection of column [5]. The 
nitride case hardening (liquid nitriding) surface treatment is used to enhance the buckling resistance of square columns with different length, material (CK45, CK67, CK101), and constant cross section $(10 \times 10) \mathrm{mm}$ subjected to the effect of single and combined dynamic loads [6]. The surface treatment by shot peening is used to enhance the buckling resistance of a series of (CK35) steel column with solid circular crosssection under single and combined dynamic loads by increasing the yield and ultimate strength of columns material [7].

Above the elastic limit of a material, the modulus of elasticity becomes a function of the stress. In other word, one should know the operating level of the stress before one can find out the modulus. This makes the analysis in the inelastic region complicated [8]. In case of columns with intermediate slenderness, i.e., columns which are stable for stresses higher than the proportionality limit, the failure of intermediate columns occurs subsequent to the onset of inelastic behavior [9]. Euler's theory may still be used, provided that the local modulus of elasticity corresponding to the critical stress is used [10]. This leads to develop the so-called tangent modulus theory and reduced modulus theory to describe the buckling behavior of intermediate columns and to predict its buckling load.

This paper examines the effect of hot-dip aluminizing process (HDA) on the dynamic buckling behavior of intermediate columns subjected to dynamic compression loading (compression and torsion), dynamic bending loading (bending and torsion, and dynamic combined loading (compression, bending, and torsion), of stainless steel (AISI 303) material by series of circular cross-section columns, of different slenderness ratio, with and without HDA surface treatment at different dipping temperatures $\left(T_{H D}\right)$ and dipping times $\left(t_{H D}\right)$.

\section{Considered Theories}

\subsection{Tangent-Modulus Theory}

In 1889, F. Engesser, a German engineer, suggested that if column failure occurred at a stress above the proportional of the material, the column strength could be obtained by simply replacing Young's modulus, $E$, in Euler's buckling formula by the tangent modulus, $E_{t},[3$, 11]. Which $E_{t}$ is the local slope of the stress-strain curve in the inelastic range, i.e., the slope of the stress-strain curve at the stress $\sigma=\frac{P_{c r}}{A}$ [12]. The elastic modulus is the $E_{t}$ (tangent modulus) if the stress is above the elastic limit of the column's material but $E$ (Young's modulus) if the stress is below the elastic limit [13]. The tangent modulus is given by $[3,11]$ :

$$
E_{t}=\frac{d \sigma}{d \varepsilon}
$$

The critical or Engesser stress may be expressed by means of modification of Euler formula in which $E_{t}$ replaces $E$ :

$\sigma_{T}=\frac{P_{c r}}{A}=\frac{\pi^{2} E_{t}}{\left(\lambda_{e}\right)^{2}}$

From the experimental tensile test results, the stress-strain curve for AISI 303 stainless steel used in this research can be represented by the following relationship:

$\sigma=2 * 10^{9} \varepsilon^{3}-4 * 10^{7} \varepsilon^{2}+286278 \varepsilon$

$$
-31.594
$$

Where $(\varepsilon)$ and $(\sigma)$ are the uniaxial strain and stress, respectively.

The tangent modulus is given by Eq. (1):

$E_{t}=\frac{d \sigma}{d \varepsilon}$

so, by differentiation of Eq. (3) with respect to $\varepsilon$, one can write:

$$
\begin{gathered}
E_{t}=\frac{d \sigma}{d \varepsilon}=6 * 10^{9} \varepsilon^{2}-8 * 10^{7} \varepsilon \\
+286278
\end{gathered}
$$

Now, substituting Eqs. (3) and (4) into Eq.(2) gives

$2 * 10^{9} \varepsilon^{3}-4 * 10^{7} \varepsilon^{2}+286278 \varepsilon-31.594=$ $\frac{\pi^{2}}{\left(\lambda_{e}\right)^{2}} *\left[6 * 10^{9} \varepsilon^{2}-8 * 10^{7} \varepsilon+286278\right]$

by rearranging Eq. (5), one can write:

$$
\begin{aligned}
& 2 * 10^{9} \varepsilon^{3}-\left(4 * 10^{7}+6 * 10^{9} * \frac{\pi^{2}}{\left(\lambda_{e}\right)^{2}}\right) \varepsilon^{2}+ \\
& \left(286278+8 * 10^{7} * \frac{\pi^{2}}{\left(\lambda_{e}\right)^{2}}\right) \varepsilon-(31.594+ \\
& \left.286278 * \frac{\pi^{2}}{\left(\lambda_{e}\right)^{2}}\right)=0
\end{aligned}
$$

Equation (6) can be solved to determine the correct value (root) of real strain $\varepsilon$ and then substitute this value in Eq. (4) to determine the value of the tangent modulus $E_{t}$ [14].

\subsection{Reduced Modulus Theory (Double Modulus Theory)}

The second modification on Euler's equation was done by $\mathrm{F}$. Engesser in 1895, by replacing $E$ (Young's modulus) by $E_{R}$ (reduced modulus) or $E_{D}$ (double modulus) which lies between the elastic modulus and tangent modulus. This suggestion led to the reduced theory or double- 
modulus theory $[8,15]$. The derivation of the general equation of $E_{R}$ is found in Refs. [8, 13] and this equation is given by the form:

$E_{R}=E \frac{I_{1}}{I_{n}}+E_{t} \frac{I_{2}}{I_{n}}$

Where the variables in Eq. (7) may be defined, with referring to Fig. (1), that represent a column of arbitrary cross-section subjected to an axial load $P$ which gradually increases. Further, the column remains perfectly straight till the critical load $P_{c r}$ is reached. At this load, the column bends slightly and the reduced modulus theory predicted that the critical stress $\sigma_{c r}$ is given by:

$\sigma_{R}=\frac{P_{c r}}{A}=\frac{\pi^{2} E_{R}}{\left(\lambda_{e}\right)^{2}}$

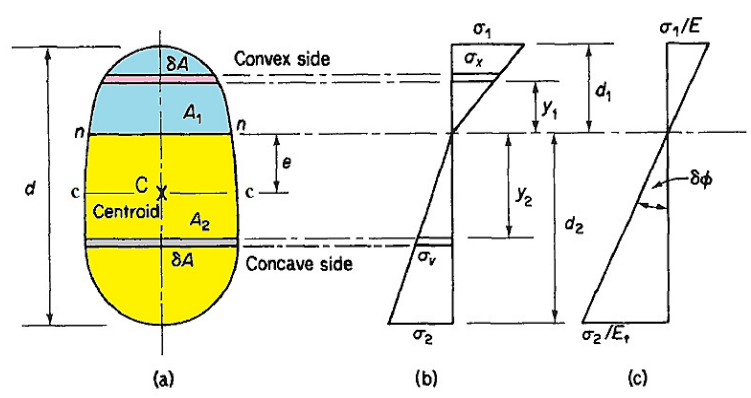

Fig. 1. Determination of reduced elastic modulus [8].

\subsubsection{Reduced Modulus for Circular Cross Section}

For the present paper requirements, the value of $I_{1}$ and $I_{2}$ must be formulated for circular crosssection in order to determine the value of $E_{R}$. Consider a column with circular cross-section, as shown in Fig. (2). Referring to Eq. (7)

$$
I_{1}=\int_{0}^{d_{1}}\left(y_{1}\right)^{2} d A
$$

Using polar coordinates system, one can write:

$y=R \sin \theta$

$\therefore$ Thickness of element,

$d y=R \cos \theta d \theta$

Length of element, $\quad x=R \cos \theta \quad \ldots(d)$

Area of element, $\quad d A=2 x d y \quad \ldots(e)$

By substituting Eq. (c) and (d) into Eq. (e), one can write:

$\therefore d A=2 R^{2}(\cos \theta)^{2} d \theta$

Now, limits of integration must be changed to polar form as follow: at $y=e \rightarrow \theta=\theta_{o}=$ $\sin ^{-1} \frac{e}{R}$ and at $y=R \rightarrow \theta=\frac{\pi}{2}$ and $y_{1}=y-e=(R \sin \theta-e)$

By substituting $y_{1}$ and $d A$ form Eqs. (g) and (f), respectively, in Eq. (a), it can be written:

$I_{1}=2 R^{2} \int_{\theta_{o}}^{\frac{\pi}{2}}(R \sin \theta-e)^{2}(\cos \theta)^{2} d A$

and $I_{n}=I+A e^{2}=\frac{\pi R^{4}}{4}+\pi R^{2} e^{2}$

Where, $I_{n}=I_{1}+I_{2}$ or $I_{2}=I_{n}-I_{1}$

By substituting $I_{n}$ and $I_{1}$ from Eqs. (h) and (9) respectively, one can write:

$$
\begin{aligned}
& I_{2}=\left(\frac{\pi R^{4}}{4}+\pi R^{2} e^{2}\right)-2 R^{2} \int_{\theta_{o}}^{\frac{\pi}{2}}(R \sin \theta- \\
& e)^{2}(\cos \theta)^{2} d A
\end{aligned}
$$

By substituting $I_{1}$ and $I_{2}$ from Eqs. (9) and (10), respectively with the values of $E$ and $E_{t}$, it can be computed the value of $E_{R}$ of the column from Eq. (7).

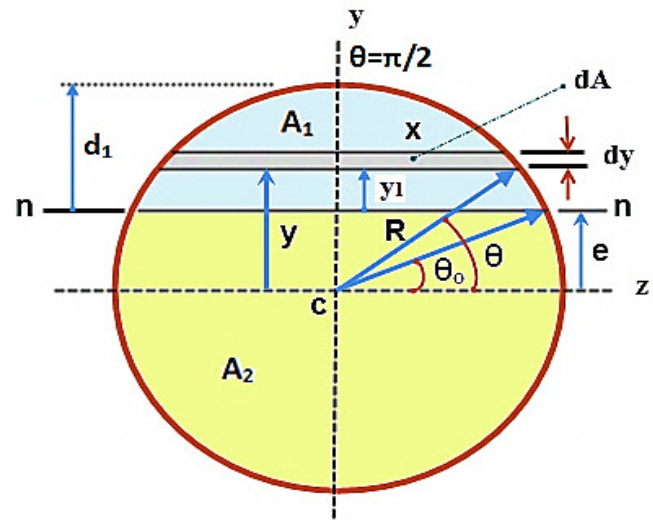

Fig. 2. Geometrical dimensions of a column with circular cross-section used in formula of reduced modulus.

\subsection{Perry Robertson Interaction Formula}

It is important to evaluate the compressive buckling strength of real columns, $\sigma_{c r}$, in the presence of initial mechanical and geometrical imperfections, a Perry Robertson interaction formula [16, 17, and 18] is adopted as follows:

$$
\sigma_{P}=\chi \sigma_{y}
$$

Where,

$\chi=\frac{1}{\varphi+\left[\varphi^{2}-(\bar{\lambda})^{2}\right]^{0.5}} \leq 1$

In which,

$$
\begin{aligned}
& \varphi=0.5\left(1+\alpha\left(\bar{\lambda}-\bar{\lambda}_{o}\right)+(\bar{\lambda})^{2}\right) \\
& \bar{\lambda}=\frac{\lambda_{e}}{\pi} \cdot \sqrt{\frac{\sigma_{y}}{E}}
\end{aligned}
$$

Where the value of the imperfection factor $(\alpha)$ and the limiting non-dimensional slenderness ratio 
$\left(\bar{\lambda}_{o}\right)$ are obtained from Ref. [9] $]^{8}$. The value of the effective slenderness ratio $\left(\lambda_{e}\right)$ is calculated by using the relation [20]:

$\lambda_{e}=\frac{K L}{r}=\frac{L_{e}}{r}$

The value of slenderness ratio under which column's type is intermediate is obtained using the following relation [15]:

$\lambda_{c}=\lambda_{e}=\pi \cdot \sqrt{\frac{E}{\sigma_{p l}}}$

and by substituting the value of $\mathrm{E}, \sigma_{p l}$ from Table (2), and the value of $\mathrm{K}=0.7$ (for fixed-pinned ends) in Eq. (16), one finds that the value of critical slenderness ratio is $\lambda_{c}=86.5$.

\section{Experimental Work}

\subsection{Material Used and Buckling Test Machine}

AISI 303 stainless steel intermediate columns of circular cross-section, $\varnothing=8 \mathrm{~mm}$, of different slenderness ratio, with and without hot-dip aluminizing were tested by using a rotating column buckling test machine capable to apply dynamic compression loading, dynamic bending loading, and compression-bending dynamic loading, with column ends support of fixedpinned and rotating speed of 17 and 34 r.p.m. In this research, low speed (17 r.p.m) was used in all dynamic buckling experiments. The photographs of the rotating buckling test machine, with some of the devices and parts of it, are shown in Fig. (3). More details of buckling test machine, used in this research, are in Ref. [5]. The detail of the chemical composition of stainless steel is shown in Table (1), and the significant mechanical properties are given in Table (2). While the experiments of hot dip aluminizing AISI 303 stainless steel rods were carried out by using a self-construction system of hot- dip aluminizing [18]. A high purity aluminum (99\%) was used for dipping bath, and the HDA process variables were dipping temperature and dipping time. The temperature of the molten aluminum bath was controlled to be within $\pm 5^{\circ} \mathrm{C}$ by using the temperature control system shown in Fig. (4). More details of the HDA system and the temperature control system, used in this research, are in Ref. [18].

\subsection{Specimens Types}

There are two types of buckling specimens used in this work, these two types are:

Type (1) as received specimens (non-aluminized): intermediate columns with circular crosssection $D=8 \mathrm{~mm}, \quad I=201.1 \mathrm{~mm}^{4}, r=2 \mathrm{~mm}$, and different lengths. Table (3) gives the geometrical dimensions and buckling parameters of these specimens.

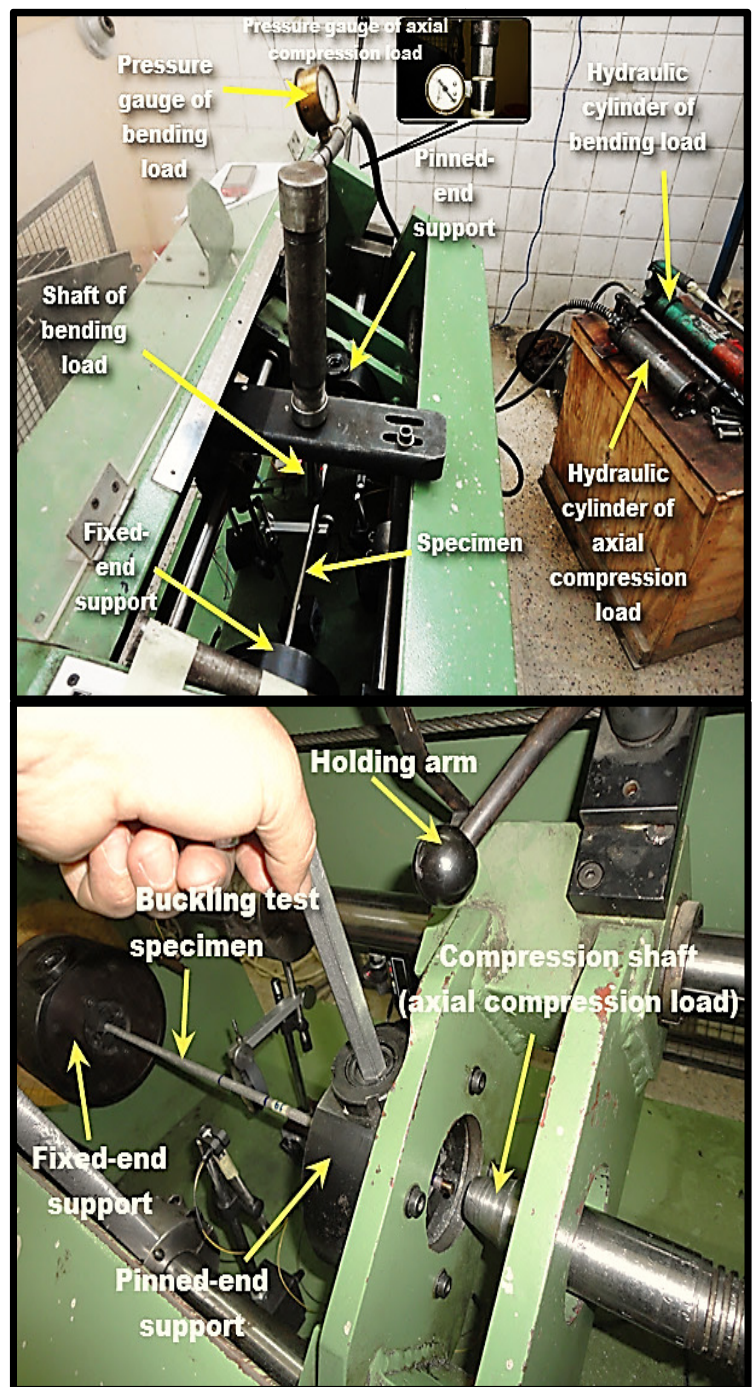

Fig. 3. The rotating buckling test machine used in the present research [18]. 
Table 1,

Chemical compositions (wt. \%) of AISI 303 stainless steel.

\begin{tabular}{lllllll}
\hline Alloy & $\mathbf{C}$ & $\mathbf{S i}$ & $\mathbf{M n}$ & $\mathbf{P}$ & $\mathbf{C r}$ & $\mathbf{N i}$ \\
\hline Used material $^{\text {a }}$ & 0.114 & 0.539 & 1.14 & 0.032 & 18.20 & 8.19 \\
\hline $\begin{array}{l}\text { Standard } \\
\text { (ASM) [17] }\end{array}$ & Up to 0.15 & Up to 1.0 & Up to 2.0 & Up to 0.2 & $17-19$ & $8-10$ \\
\hline $\begin{array}{l}\text { a: Source: State Company for Inspection and Engineering Rehabilitation (SIER)/Baghdad. } \\
\text { S }\end{array}$ & & &
\end{tabular}

a: Source: State Company for Inspection and Engineering Rehabilitation (SIER)/Baghdad.

Table 2,

Experimental mechanical properties of AISI 303 stainless steel used in present work (Average of three specimens).

\begin{tabular}{llllll}
\hline AISI 303 st. st. & $\begin{array}{l}\boldsymbol{\sigma}_{\text {ult }} \\
(\mathbf{M P a})\end{array}$ & $\begin{array}{l}\boldsymbol{\sigma}_{\boldsymbol{y}} * \\
(\mathbf{M P a})\end{array}$ & $\begin{array}{l}\mathbf{E} \\
(\mathbf{G P a})\end{array}$ & $\begin{array}{l}\text { Elong.** } \\
\boldsymbol{\%}\end{array}$ & $\begin{array}{l}\boldsymbol{\sigma}_{\boldsymbol{p l}} \\
(\mathbf{M P a})\end{array}$ \\
\hline & 880 & 673 & 204.2 & 41.4 & 269.2 \\
\hline
\end{tabular}

* Proof stress at $0.2 \%$ of stain.

** In gauge length $L_{o}=25 \mathrm{~mm}$.
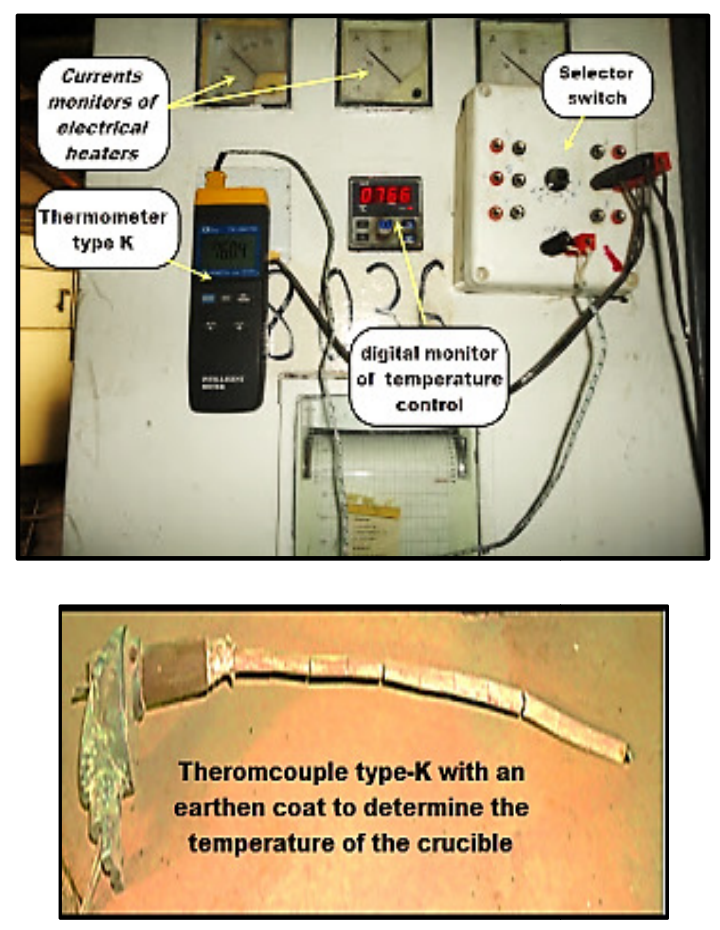

Fig. 4. Temperature control system used to control the temperature of the molten aluminum [18].

Type (2) aluminized specimens: intermediate hotdip aluminized (HDA) columns with circular cross-section. These specimens have a constant length $\mathrm{L}=200 \mathrm{~mm}$, but at different hot-dip conditions from dipping temperature (700, 740,
780,820 , and $\left.860^{\circ} \mathrm{C}\right)$ and different dipping times $(1,2,3,4$, and 5 minutes). Table (4) gives the parameters of hot-dip and buckling of these specimens. It should be noted that the thickness of the aluminum layer, to be formed during the HDA process, is in the micrometer. So, the effect of the HDA process in changing of the cross sectional area of aluminized column it can be neglected in calculations the values of critical buckling stresses.

\subsection{Failure Criterion of Buckling}

When the maximum deflection of the column reaches the critical value of deflection $\left(\delta_{c r}\right)$ of the column length, then the load measured (by pressure gauge) is the critical buckling load of the column. In the present work, the value of the critical deflection of the column is taken was $\left(\delta_{c r}(m m)=(L * 1 \%)+\delta_{o}\right) \quad[6,16$, and 18]. Because of the rotating effect on the reading of the column deflection using a dial gauge, a laser cell circuit tool was fabricated, with whistle sound, fixed on electronic vernier (with a reading accuracy of $0.01 \mathrm{~mm}$ ), Fig. (5), to make the reading of critical deflection $\left(\delta_{c r}\right)$ more strict. 
Table 3,

Geometrical dimensions and buckling parameters of specimens type (1)

\begin{tabular}{|c|c|c|c|c|c|c|c|c|}
\hline No. & Symbol & $L(\mathbf{m m})$ & $\begin{array}{l}L_{e}^{*} \\
(\mathbf{m m})\end{array}$ & $\begin{array}{c}\boldsymbol{\delta}_{o} \\
(\mathbf{m m})\end{array}$ & $\begin{array}{l}\boldsymbol{\delta}_{c r}^{* *} \\
(\mathbf{m m})\end{array}$ & $\begin{array}{c}\lambda_{e} \\
\left(=\frac{L_{e}}{r}\right)\end{array}$ & $\begin{array}{l}\text { Type of } \\
\text { loading }\end{array}$ & $\begin{array}{l}\text { Type } \\
\text { of column }\end{array}$ \\
\hline \multirow[t]{3}{*}{1} & $1 \mathrm{a}$ & \multirow{3}{*}{160} & \multirow{3}{*}{112} & $0.55 / 2$ & 1.88 & \multirow{3}{*}{56} & compression & \multirow{3}{*}{ Intermediate } \\
\hline & $1 b$ & & & $0.2 / 2$ & 1.7 & & bending & \\
\hline & $1 \mathrm{c}$ & & & $0.9 / 2$ & 2.05 & & combined & \\
\hline \multirow[t]{3}{*}{2} & $2 \mathrm{a}$ & \multirow{3}{*}{170} & \multirow{3}{*}{119} & $0.6 / 2$ & 2 & \multirow{3}{*}{59.5} & compression & \multirow{3}{*}{ Intermediate } \\
\hline & $2 b$ & & & $0.25 / 2$ & 1.83 & & bending & \\
\hline & $2 c$ & & & $1.1 / 2$ & 2.25 & & combined & \\
\hline \multirow[t]{3}{*}{3} & $3 a$ & \multirow{3}{*}{180} & \multirow{3}{*}{126} & $0.71 / 2$ & 2.16 & \multirow{3}{*}{63} & compression & \multirow{3}{*}{ Intermediate } \\
\hline & $3 b$ & & & $0.85 / 2$ & 2.23 & & bending & \\
\hline & $3 c$ & & & $1.35 / 2$ & 2.48 & & combined & \\
\hline \multirow[t]{3}{*}{4} & $4 a$ & \multirow{3}{*}{190} & \multirow{3}{*}{133} & $0.96 / 2$ & 2.38 & \multirow{3}{*}{66.5} & compression & \multirow{3}{*}{ Intermediate } \\
\hline & $4 b$ & & & $0.5 / 2$ & 2.15 & & bending & \\
\hline & $4 c$ & & & $1.3 / 2$ & 2.55 & & combined & \\
\hline \multirow[t]{3}{*}{5} & $5 a$ & \multirow{3}{*}{200} & \multirow{3}{*}{140} & $0.8 / 2$ & 2.4 & \multirow{3}{*}{70} & compression & \multirow{3}{*}{ Intermediate } \\
\hline & $5 b$ & & & $0.25 / 2$ & 2.13 & & bending & \\
\hline & $5 c$ & & & $1.3 / 2$ & 2.65 & & combined & \\
\hline \multirow[t]{3}{*}{6} & $6 a$ & \multirow{3}{*}{210} & \multirow{3}{*}{147} & $1.22 / 2$ & 2.71 & \multirow{3}{*}{73.5} & compression & \multirow{3}{*}{ Intermediate } \\
\hline & $6 b$ & & & $0.34 / 2$ & 2.27 & & bending & \\
\hline & $6 c$ & & & $1.46 / 2$ & 2.83 & & combined & \\
\hline \multirow[t]{3}{*}{7} & $7 a$ & & & $1.1 / 2$ & 2.75 & & compression & \\
\hline & $7 b$ & 220 & 154 & $0.72 / 2$ & 2.56 & 77 & bending & Intermediate \\
\hline & $7 \mathrm{c}$ & & & $1.65 / 2$ & 3.03 & & Combined & \\
\hline 8 & $8 \mathrm{a}$ & & & $1.21 / 2$ & 2.91 & & $\begin{array}{c}\text { Compressio } \\
\mathrm{n}\end{array}$ & \\
\hline & $8 b$ & 230 & 161 & $0.7 / 2$ & 2.65 & 80.5 & Bending & Intermediate \\
\hline & $8 c$ & & & $1.6 / 2$ & 3.1 & & Combined & \\
\hline 9 & $9 a$ & & & $1.2 / 2$ & 3 & & $\underset{n}{\text { Compressio }}$ & \\
\hline & $9 b$ & 240 & 168 & $0.82 / 2$ & 2.81 & 84 & Bending & Intermediate \\
\hline & $9 \mathrm{c}$ & & & $1.7 / 2$ & 3.25 & & Combined & \\
\hline
\end{tabular}

${ }^{*} L_{e}=K L ; K=0.7$ for Fixed-pinned supports; ${ }^{* *} \delta_{c r}(m m)=(L * 1 \%)+\delta_{o} ;{ }^{* * *}$ Compression load= (compressiontorsion) load; Bending load= (bending-torsion) load. Bending load at mid span; Combined load= (compression-

bending-torsion load). Bending load at mid span); ${ }^{* * * *} \lambda_{c}=\pi \cdot \sqrt{\frac{E}{\sigma_{p l}}}=86.5$, if $\lambda_{e}<\lambda_{c} \rightarrow$ intermediat column. 
Table 4,

Geometrical dimensions and buckling parameters of the hot-dip aluminized columns type 2 (intermediate columns)

\begin{tabular}{|c|c|c|c|c|c|c|c|c|c|c|}
\hline & No. & $\begin{array}{c}\text { Dipping } \\
\text { temperature } \\
T_{H D}\left({ }^{\circ} \mathrm{C}\right)\end{array}$ & $\begin{array}{c}\text { Dipping } \\
\text { time } t_{H D} \\
\quad(\mathrm{~min})\end{array}$ & $\begin{array}{c}L \\
(\mathbf{m m})\end{array}$ & $\begin{array}{c}L_{e} \\
(\mathbf{m m})\end{array}$ & $\delta_{o}(\mathbf{m m})$ & $\delta_{c r}(\mathbf{m m})$ & $\lambda_{e}$ & $\begin{array}{l}\text { Type of } \\
\text { column }\end{array}$ & $\begin{array}{l}\text { Type of } \\
\text { loading }\end{array}$ \\
\hline \multirow{5}{*}{ A1 } & 1 & \multirow{5}{*}{700} & 1 & \multirow{5}{*}{200} & \multirow{5}{*}{140} & $0.75 / 2$ & 2.43 & \multirow{5}{*}{70} & \multirow{5}{*}{ Intermediate } & \multirow{5}{*}{ Compression } \\
\hline & 2 & & 2 & & & $0.74 / 2$ & 2.3 & & & \\
\hline & 3 & & 3 & & & $1.2 / 2$ & 2.38 & & & \\
\hline & 4 & & 4 & & & $0.85 / 2$ & 2.37 & & & \\
\hline & 5 & & 5 & & & $0.6 / 2$ & 2.45 & & & \\
\hline \multirow{6}{*}{ B1 } & 6 & \multirow{5}{*}{740} & 1 & \multirow{5}{*}{200} & \multirow{5}{*}{140} & $0.75 / 2$ & 2.38 & \multirow{5}{*}{70} & \multirow{5}{*}{ Intermediate } & \multirow{5}{*}{ Compression } \\
\hline & 7 & & 2 & & & $0.74 / 2$ & 2.26 & & & \\
\hline & 8 & & 3 & & & $0.9 / 2$ & 2.28 & & & \\
\hline & 9 & & 4 & & & $0.75 / 2$ & 2.45 & & & \\
\hline & 10 & & 5 & & & $0.43 / 2$ & 2.34 & & & \\
\hline & 11 & \multirow{5}{*}{780} & 1 & \multirow{5}{*}{200} & \multirow{5}{*}{140} & $0.55 / 2$ & 2.35 & \multirow{5}{*}{70} & \multirow{5}{*}{ Intermediate } & \multirow{5}{*}{ Compression } \\
\hline \multirow{4}{*}{$\mathrm{C} 1$} & 12 & & 2 & & & $0.9 / 2$ & 2.13 & & & \\
\hline & 13 & & 3 & & & $0.68 / 2$ & 2.36 & & & \\
\hline & 14 & & 4 & & & $0.7 / 2$ & 2.5 & & & \\
\hline & 15 & & 5 & & & $0.25 / 2$ & 2.49 & & & \\
\hline \multirow{5}{*}{ D1 } & 16 & & 1 & & & $0.72 / 2$ & 2.35 & & & \\
\hline & 17 & & 2 & & & $1 / 2$ & 2.45 & & & \\
\hline & 18 & 820 & 3 & 200 & 140 & $0.98 / 2$ & 2.3 & 70 & Intermediate & Compression \\
\hline & 19 & & 4 & & & $0.7 / 2$ & 2.6 & & & \\
\hline & 20 & & 5 & & & $0.9 / 2$ & 2.45 & & & \\
\hline & 21 & & 1 & & & $0.6 / 2$ & 2.55 & & & \\
\hline & 22 & & 2 & & & $1.2 / 2$ & 2.46 & & & \\
\hline E1 & 23 & 860 & 3 & 200 & 140 & $0.9 / 2$ & 2.43 & 70 & Intermediate & Compression \\
\hline & 24 & & 4 & & & $1.1 / 2$ & 2.3 & & & \\
\hline & 25 & & 5 & & & $0.92 / 2$ & 2.38 & & & \\
\hline & 26 & & 1 & & & $0.75 / 2$ & 2.38 & & & \\
\hline & 27 & & 2 & & & $0.7 / 2$ & 2.35 & & & \\
\hline $\mathrm{A} 2$ & 28 & 700 & 3 & 200 & 140 & $0.6 / 2$ & 2.3 & 70 & Intermediate & Bending \\
\hline & 29 & & 4 & & & $0.55 / 2$ & 2.28 & & & \\
\hline & 30 & & 5 & & & $0.7 / 2$ & 2.35 & & & \\
\hline & 31 & & 1 & & & $0.6 / 2$ & 2.3 & & & \\
\hline & 32 & & 2 & & & $0.6 / 2$ & 2.3 & & & \\
\hline B2 & 33 & 740 & 3 & 200 & 140 & $0.4 / 2$ & 2.2 & 70 & Intermediate & Bending \\
\hline & 34 & & 4 & & & $0.48 / 2$ & 2.24 & & & \\
\hline & 35 & & 5 & & & $0.5 / 2$ & 2.25 & & & \\
\hline & 36 & & 1 & & & $0.67 / 2$ & 2.34 & & & \\
\hline & 37 & & 2 & & & $0.35 / 2$ & 2.18 & & & \\
\hline $\mathrm{C} 2$ & 38 & 780 & 3 & 200 & 140 & $1 / 2$ & 2.5 & 70 & Intermediate & Bending \\
\hline & 39 & & 4 & & & $0.9 / 2$ & 2.45 & & & \\
\hline & 40 & & 5 & & & $0.65 / 2$ & 2.33 & & & \\
\hline & 41 & & 1 & & & $0.9 / 2$ & 2.45 & & & \\
\hline D2 & 42 & 820 & 2 & 200 & 140 & $0.6 / 2$ & 2.3 & 70 & Intermediate & Bending \\
\hline & 43 & & 3 & & & $0.8 / 2$ & 2.4 & & & \\
\hline
\end{tabular}


Table 4 (continue)

\begin{tabular}{|c|c|c|c|c|c|c|c|c|c|c|}
\hline & \multirow{2}{*}{$\begin{array}{l}44 \\
45\end{array}$} & & 4 & & & $1.2 / 2$ & 2.6 & & & \\
\hline & & & 5 & & & $0.98 / 2$ & 2.49 & & & \\
\hline \multirow{5}{*}{ E2 } & 46 & \multirow{5}{*}{860} & 1 & \multirow{5}{*}{200} & \multirow{5}{*}{140} & $1 / 2$ & 2.5 & \multirow{5}{*}{70} & \multirow{5}{*}{ Intermediate } & \multirow{5}{*}{ Bending } \\
\hline & 47 & & 2 & & & $0.85 / 2$ & 2.43 & & & \\
\hline & 48 & & 3 & & & $0.8 / 2$ & 2.4 & & & \\
\hline & 49 & & 4 & & & $0.98 / 2$ & 2.49 & & & \\
\hline & 50 & & 5 & & & $0.25 / 2$ & 2.13 & & & \\
\hline \multirow{5}{*}{ A3 } & 51 & \multirow{5}{*}{700} & 1 & \multirow{5}{*}{200} & \multirow{5}{*}{140} & $1.14 / 2$ & 2.57 & \multirow{5}{*}{70} & \multirow{5}{*}{ Intermediate } & \multirow{5}{*}{ Combined } \\
\hline & 52 & & 2 & & & $1.15 / 2$ & 2.58 & & & \\
\hline & 53 & & 3 & & & $1 / 2$ & 2.5 & & & \\
\hline & 54 & & 4 & & & $0.95 / 2$ & 2.48 & & & \\
\hline & 55 & & 5 & & & $0.7 / 2$ & 2.35 & & & \\
\hline \multirow{5}{*}{ B3 } & 56 & \multirow{5}{*}{740} & 1 & \multirow{5}{*}{200} & \multirow{5}{*}{140} & $1.12 / 2$ & 2.56 & \multirow{5}{*}{70} & \multirow{5}{*}{ Intermediate } & \multirow{5}{*}{ Combined } \\
\hline & 57 & & 2 & & & $0.9 / 2$ & 2.45 & & & \\
\hline & 58 & & 3 & & & $1.12 / 2$ & 2.56 & & & \\
\hline & 59 & & 4 & & & $0.9 / 2$ & 2.45 & & & \\
\hline & 60 & & 5 & & & $0.62 / 2$ & 2.31 & & & \\
\hline & 61 & & 1 & & & $1.2 / 2$ & 2.6 & & & \\
\hline & 62 & & 2 & & & $0.5 / 2$ & 2.25 & & & \\
\hline $\mathrm{C} 3$ & 63 & 780 & 3 & 200 & 140 & $1.2 / 2$ & 2.6 & 70 & Intermediate & Combined \\
\hline & 64 & & 4 & & & $0.7 / 2$ & 2.35 & & & \\
\hline & 65 & & 5 & & & $0.45 / 2$ & 2.23 & & & \\
\hline & 66 & & 1 & & & $0.84 / 2$ & 2.42 & & & \\
\hline & 67 & & 2 & & & $0.6 / 2$ & 2.3 & & & \\
\hline D3 & 68 & 820 & 3 & 200 & 140 & $0.5 / 2$ & 2.25 & 70 & Intermediate & Combined \\
\hline & 69 & & 4 & & & $1.12 / 2$ & 2.56 & & & \\
\hline & 70 & & 5 & & & $0.82 / 2$ & 2.41 & & & \\
\hline & 71 & & 1 & & & $1.2 / 2$ & 2.6 & & & \\
\hline & 72 & & 2 & & & $0.95 / 2$ & 2.48 & & & \\
\hline E3 & 73 & 860 & 3 & 200 & 140 & $0.5 / 2$ & 2.25 & 70 & Intermediate & Combined \\
\hline & 74 & & 4 & & & $0.5 / 2$ & 2.25 & & & \\
\hline & 75 & & 5 & & & $1.42 / 2$ & 2.71 & & & \\
\hline
\end{tabular}

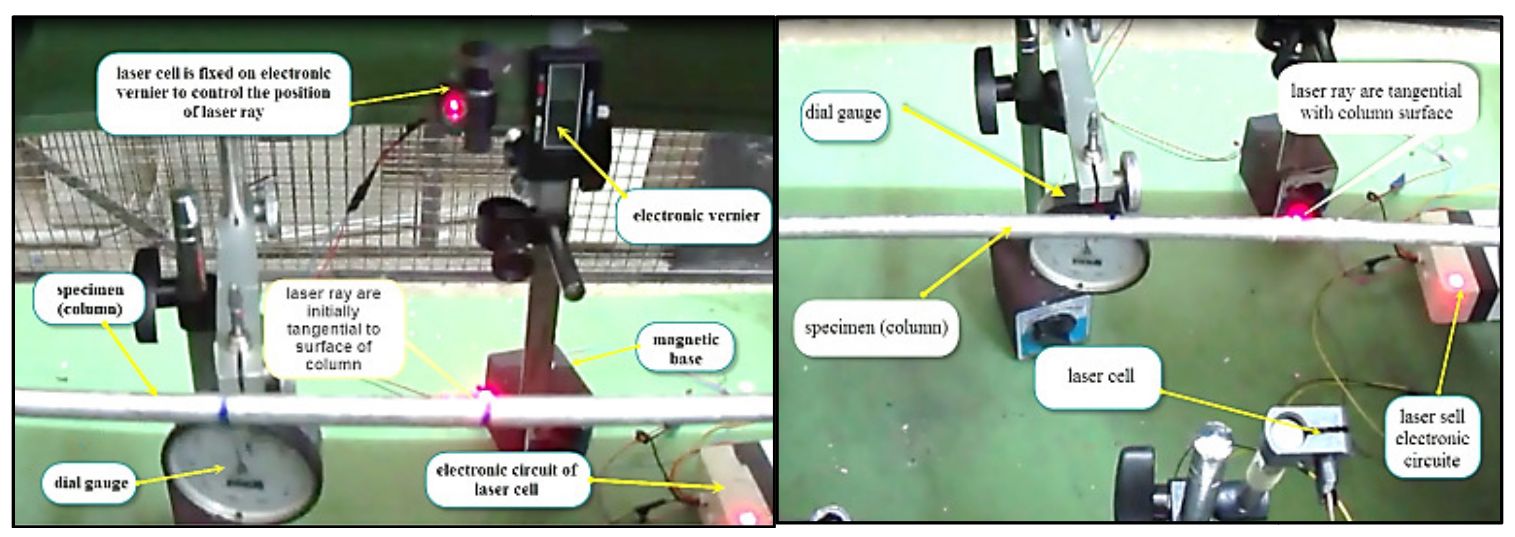

Fig. 5. System used to control the deflection of columns during buckling test. 


\section{Results and Discussion}

Table (5) shows the experimental results of dynamic buckling test of 303 AISI column specimens without aluminizing (type 1). In this table, it can be observed that the critical buckling load $\left(P_{\text {exp }}\right)$ decreased with increasing in effective slenderness ratio $\left(\lambda_{e}\right)$ for both dynamic compression load (compression-torsion load) and dynamic combined load (compression-bendingtorsion load). Also, it can be seen that the bending stress $\left(\sigma_{\text {ben. }}\right)$ is greater than the critical buckling stress for all slenderness ratios, but is also decreased with increased $\lambda_{e}$. In order to make a comparison between the experimental results and theoretical results, tangent modulus theory, reduced modulus theory and Perry-Robertson interaction formula are used to calculate the theoretical critical buckling stress for the specimens of type (1), and the results are shown in Table (6). From Table (5) and Table (6), it can be observed that the experimental critical stress $\left(\sigma_{\text {exp }}\right)$ is, in general, lower than the value of theoretical critical stress $\left(\sigma_{T}, \sigma_{R}\right.$, and $\left.\sigma_{P}\right)$ from tangent modulus theory, reduced modulus theory, and Perry Robertson interaction formula, respectively. The difference between the experimental and theoretical results is due to in both tangent modules and reduced modulus theories, the column is assumed as a perfect column (no initial imperfection) and the applied load is gradually increased with no dynamic effect (torsion load) and with no lateral load (bending load). In Perry-Robertson formula, effect of the initial imperfection is considered, but the dynamic effect of loading is not considered. In general, it can be observed that the results obtained by using Perry-Robertson formula are more accurate compared with results obtained using tangent modulus theory and reduced modulus theory.

Table (7) shows the experimental results of dynamic buckling test of specimens type 2 (hotdip aluminized intermediate columns) with constant slenderness ratio of $\lambda_{e}=70$ and different hot-dip conditions (dipping temperature and dipping time). From Table (7), it can be detected that there is enhancement in buckling resistance of intermediate aluminized columns under dynamic compression load (compression and torsion), dynamic bending load (bending and torsion), and dynamic combined load (compression, bending, and torsion). In order to show the improvement of dynamic buckling resistance of aluminized columns (type 2) compared with non-aluminized columns (type 1), Fig. (6) and Fig. (7) are plotted by using the experimental results of Table (5) for specimens type (1), and Table (7) for specimens type (2), whereas Table (6) gives the theoretical results from tangent modulus theory, reduced modulus theory, and Perry Robertson interaction formula. The improvement of buckling resistance, based on the average value of experimental critical buckling stress $\left(\sigma_{\text {exp }}\right)$, is as follow: $(19.4 \%)$ for intermediate columns type (2) compared with columns type (1), under dynamic compression loading, and $(8.7 \%)$ for intermediate columns type (2), compared with columns type (1) under dynamic bending loading, and $(16.5 \%)$ for intermediate columns type (2) compared with columns type (1) under dynamic combined loading. These enhancement ratios of buckling resistance are illustrated in Fig. (8).

It should be noted that the effect of rotating of the column (torsional loading) during the applied of compression load and/or compression-bending loads was appeared clearly first by a Spatial (nonplanar) shape of column deformation until buckling is occur and second by reducing the value of the critical buckling load. The lateral loading (bending load) on the rotating columns leads to a fast increasing in the lateral deflection of the column under combined loading conditions and a signification reduction in the axial compressive load and as a result, it decreases the buckling resistance of the columns compared with the case without lateral loading. It is experimentally noted that the effect of the lateral loading on the buckling resistance was much greater than the effect of the twisting or torsional loading for the same slenderness ratios. Under dynamic compression loading, Fig. (9), the buckling resistance of HDA columns (type 2) is decreased with the increase in dipping time $\left(t_{H D}\right)$ for hot-dip conditions of $740{ }^{\circ} \mathrm{C}, 780{ }^{\circ} \mathrm{C}$, and 860 ${ }^{\circ} \mathrm{C}$, but the buckling resistance is increased with the increase in dipping time for hot-dip conditions of $700{ }^{\circ} \mathrm{C}$, and $820^{\circ} \mathrm{C}$ with maximum value of increasing at $700^{\circ} \mathrm{C}$. Under dynamic bending load, Fig. (10), the bending resistance of HDA columns is approximately remained constant with increasing in dipping time. Under dynamic combined load, Fig. (11), the buckling resistance is generally increased with the increase in dipping time from 1 minute to approximately 4 minutes and then decreased for all dipping temperatures except the dipping temperature $740^{\circ} \mathrm{C}$, where the buckling resistance decreased with the increase in 
dipping time from 1 minute to 3 minutes and then increased with dipping time. The bending resistance of HDA columns, Fig. (11), under dynamic combined loading is decreased with the increase in dipping time at $700^{\circ} \mathrm{C}, 780^{\circ} \mathrm{C}$, and $860^{\circ} \mathrm{C}$, but it is increased with the increase in dipping time at $740{ }^{\circ} \mathrm{C}$, and $820^{\circ} \mathrm{C}$. From the above discussion, it can be noticed that the HDA conditions of dipping time 3 minutes and dipping temperature of $700{ }^{\circ} \mathrm{C}$ and/ or $820{ }^{\circ} \mathrm{C}$ give maximum buckling resistance under both dynamic compression load and dynamic combined load.

\section{Conclusions}

1. The experimental values of the critical buckling stress $\left(\sigma_{\text {exp }}\right)$ for non-aluminized intermediate columns, $\left(\lambda_{e}<\lambda_{c}, \lambda_{e}\right.$ (56 to 84), are less than the theoretical values of critical buckling stress $\left(\sigma_{T}, \sigma_{R}\right.$, and $\left.\sigma_{P}\right)$ predicted by tangent modulus theory, reduced modulus theory, and Perry Robertson interaction formula, respectively. The average decreasing in percentage for values of the experimental critical buckling stress under dynamic compression load compared with the theoretical values of critical buckling stress are: $-51.015 \%$. (Tangent modulus theory), $50.44 \%$ (Reduced modulus theory), and $29.143 \%$ (Perry-Robertson formula).

2. Using of hot- dip aluminizing surface treatment has made two benefits, one of them is to develop a protection layer for the substrate material from the environment conditions, and the other is the improvement of dynamic buckling resistance of intermediate aluminized columns under dynamic compression loading, dynamic bending loading, and under dynamic combined loading.
3. The improvement in the dynamic buckling resistance was $(19.4 \%)$ for intermediate columns type (2) compared with columns type (1) under dynamic compression loading, $(8.7 \%)$ for intermediate columns type (2) compared with columns type (1) under dynamic bending loading, and $(16.5 \%)$ for intermediate columns type (2) compared with columns type (1) under dynamic combined loading.

4. The optimum hot-dip aluminizing conditions, that give a maximum enhancement of dynamic buckling resistance for the specimens of type (2), are: dipping time of ( $\mathrm{t}_{\mathrm{HD}}=3$ to $\left.4 \mathrm{~min}\right)$ and dipping temperature of $\left(\mathrm{T}_{\mathrm{HD}}=700^{\circ} \mathrm{C}\right.$ and $820^{\circ} \mathrm{C}$ ).

5. The effect of the torsional loading during the application of compression load, bending load, and compression-bending loads was appeared clearly first by a spatial (non-planar) shape of column deformation until buckling is occurred and second by effecting on the value of the critical buckling load. while, The lateral loading (bending load) on the rotating columns leads to a fast increasing in the lateral deflection of the column under combined loading conditions and a signification reduction in the axial compressive load (critical buckling load).

6. The average decreasing in percentage for values of the experimental critical buckling load under dynamic combined load (for as received specimens and HDA specimens), is $49.6 \%$ compared with values of the experimental critical buckling load without lateral bending load (under dynamic compression load) for the same effective slenderness ratios. 
Table 5,

Experimental results of dynamic buckling test of column specimen's type (1)

\begin{tabular}{|c|c|c|c|c|c|c|}
\hline No. & Symbol & $\begin{array}{l}\text { Type of } \\
\text { loading }\end{array}$ & $\begin{array}{c}\boldsymbol{P}_{\text {exp }} \\
(\boldsymbol{N})\end{array}$ & $\begin{array}{c}\sigma_{\exp } \\
(\boldsymbol{M P a})\end{array}$ & $\begin{array}{c}\boldsymbol{F}_{\boldsymbol{b e n}} . \\
(\boldsymbol{N})\end{array}$ & $\begin{array}{c}\sigma_{b e n} \\
(\boldsymbol{M P a})\end{array}$ \\
\hline \multirow[t]{3}{*}{1} & $1 \mathrm{a}$ & Comp. & 16257.742 & 323.4375 & --- & --- \\
\hline & $1 \mathrm{~b}$ & Ben. & --- & --- & 530.4 & 263.79936 \\
\hline & $1 \mathrm{c}$ & Comb. & 7775.442 & 154.688 & 489.6 & 243.507 \\
\hline \multirow[t]{3}{*}{2} & $2 a$ & Comp. & 14844.025 & 295.3125 & --- & --- \\
\hline & $2 b$ & Ben. & --- & --- & 510 & 269.50655 \\
\hline & $2 c$ & Comb. & 7068.583 & 140.625 & 469.2 & 247.946 \\
\hline \multirow[t]{3}{*}{3} & $3 a$ & Comp. & 13783.738 & 274.2188 & --- & --- \\
\hline & $3 b$ & Ben. & --- & --- & 489.6 & 273.94549 \\
\hline & $3 c$ & Comb. & 6361.725 & 126.563 & 448.8 & 251.117 \\
\hline \multirow[t]{3}{*}{4} & $4 a$ & Comp. & 12370.021 & 246.0938 & --- & --- \\
\hline & $4 \mathrm{~b}$ & Ben. & --- & --- & 469.2 & 277.11615 \\
\hline & $4 c$ & Comb. & 6008.296 & 119.531 & 428.4 & 253.019 \\
\hline \multirow[t]{3}{*}{5} & $5 a$ & Comp. & 10956.304 & 217.9688 & --- & --- \\
\hline & $5 b$ & Ben. & --- & --- & 448.8 & 279.01855 \\
\hline & $5 c$ & Comb. & 5654.867 & 112.5 & 408 & 253.653 \\
\hline \multirow[t]{3}{*}{6} & $6 a$ & Comp. & 10249.446 & 203.9063 & --- & --- \\
\hline & $6 b$ & Ben. & --- & --- & 428.4 & 279.65268 \\
\hline & $6 c$ & Comb. & 5301.434 & 105.469 & 387.6 & 253.019 \\
\hline \multirow[t]{3}{*}{7} & $7 a$ & Comp. & 9542.5877 & 189.8438 & --- & --- \\
\hline & $7 b$ & Ben. & --- & --- & 408 & 279.01855 \\
\hline & $7 \mathrm{c}$ & Comb. & 4948.008 & 98.438 & 367.2 & 251.117 \\
\hline \multirow[t]{3}{*}{8} & $8 a$ & Comp. & 9189.1585 & 182.8125 & --- & --- \\
\hline & $8 b$ & Ben. & --- & --- & 387.6 & 277.11615 \\
\hline & $8 \mathrm{c}$ & Comb. & 4806.637 & 95.625 & 346.8 & 247.946 \\
\hline \multirow[t]{3}{*}{9} & $9 a$ & Comp. & 8482.3002 & 168.75 & --- & --- \\
\hline & $9 b$ & Ben. & --- & --- & 367.2 & 273.94549 \\
\hline & $9 c$ & Comb. & 4665.265 & 92.813 & 326.4 & 243.507 \\
\hline
\end{tabular}

Table 6,

Theoretical values of critical buckling stress using tangent modulus theory, reduced modulus theory, and PerryRobertson formula for specimens of type (1).

\begin{tabular}{cccccccccc}
\hline No. & $\begin{array}{c}\boldsymbol{L} \\
(\mathbf{m m})\end{array}$ & $\begin{array}{c}\boldsymbol{L}_{\boldsymbol{e}} \\
(\mathbf{m m})\end{array}$ & $\begin{array}{c}\lambda_{\boldsymbol{e}} \\
\left(=\frac{\boldsymbol{L}_{\boldsymbol{e}}}{\boldsymbol{r}}\right)\end{array}$ & $\begin{array}{c}\boldsymbol{\delta}_{\boldsymbol{c r}} \\
(\boldsymbol{m m})\end{array}$ & $\begin{array}{c}\boldsymbol{E}_{\boldsymbol{t}} \\
(\boldsymbol{G P a})\end{array}$ & $\begin{array}{c}\boldsymbol{\sigma}_{\boldsymbol{T}} \\
(\boldsymbol{M P a})\end{array}$ & $\begin{array}{c}\boldsymbol{E}_{\boldsymbol{R}} \\
(\boldsymbol{G P a})\end{array}$ & $\begin{array}{c}\boldsymbol{\sigma}_{\boldsymbol{R}} \\
(\boldsymbol{M P a})\end{array}$ & $\begin{array}{c}\boldsymbol{\sigma}_{\boldsymbol{P}} \\
(\boldsymbol{M P a})\end{array}$ \\
\hline 1 & 160 & 112 & 56 & 1.88 & 137.131 & 431.578 & 139.343 & 438.539 & 391.878 \\
2 & 170 & 119 & 59.5 & 2 & 146.248 & 407.714 & 147.706 & 411.779 & 365.339 \\
3 & 180 & 126 & 63 & 2.16 & 154.764 & 384.847 & 155.667 & 387.093 & 340.049 \\
4 & 190 & 133 & 66.5 & 2.38 & 162.686 & 363.084 & 163.1 & 364.008 & 316.270 \\
5 & 200 & 140 & 70 & 2.4 & 170.035 & 342.485 & 170.335 & 343.089 & 294.137 \\
6 & 210 & 147 & 73.5 & 2.71 & 176.836 & 323.069 & 176.934 & 323.248 & 273.684 \\
7 & 220 & 154 & 77 & 2.75 & 183.123 & 304.832 & 183.189 & 304.942 & 254.878 \\
8 & 230 & 161 & 80.5 & 2.905 & 188.928 & 287.743 & 188.956 & 287.785 & 237.640 \\
9 & 240 & 168 & 84 & 3 & 194.288 & 271.761 & 194.3 & 271.777 & 221.866 \\
\hline
\end{tabular}


Table 7,

Experimental results of dynamic buckling test of the hot-dip aluminized columns type 2 (intermediate columns).

\begin{tabular}{|c|c|c|c|c|c|c|c|c|c|c|c|c|c|}
\hline & No. & $\begin{array}{c}P_{\text {exp }} \\
(\boldsymbol{N})\end{array}$ & $\begin{array}{c}\sigma_{\exp } \\
(\boldsymbol{M P a})\end{array}$ & & No. & $\begin{array}{c}\boldsymbol{F}_{\text {ben. }} \\
(\boldsymbol{N})\end{array}$ & $\begin{array}{c}\sigma_{\text {ben }} \\
(\boldsymbol{M P a})\end{array}$ & & No. & $\begin{array}{c}P_{\text {exp }} \\
(\boldsymbol{N})\end{array}$ & $\begin{array}{c}\sigma_{\exp } \\
(\boldsymbol{M P a})\end{array}$ & $\begin{array}{c}\boldsymbol{F}_{\text {ben. }} \\
(\boldsymbol{N})\end{array}$ & $\begin{array}{c}\sigma_{\text {ben }} \\
(\text { MPa })\end{array}$ \\
\hline \multirow{5}{*}{ A1 } & 1 & 13430.309 & 267.188 & \multirow{5}{*}{ A 2} & 26 & 448.8 & 279.018 & \multirow{5}{*}{ A3 } & 51 & 22950 & 456.576 & 530.4 & 329.749 \\
\hline & 2 & 12723.450 & 253.125 & & 27 & 693.6 & 431.210 & & 52 & 28687.5 & 570.719 & 510 & 317.066 \\
\hline & 3 & 15550.884 & 309.375 & & 28 & 448.8 & 279.018 & & 53 & 48768.75 & 970.223 & 489.6 & 304.384 \\
\hline & 4 & 12016.592 & 239.063 & & 29 & 448.8 & 279.018 & & 54 & 25818.75 & 513.648 & 408 & 253.653 \\
\hline & 5 & 14844.025 & 295.313 & & 30 & 448.8 & 279.018 & & 55 & 45900 & 913.151 & 367.2 & 228.287 \\
\hline \multirow{5}{*}{ B1 } & 6 & 14137.167 & 281.25 & \multirow{5}{*}{ B2 } & 31 & 448.8 & 279.018 & \multirow{5}{*}{ B3 } & 56 & 25818.75 & 513.648 & 408 & 253.653 \\
\hline & 7 & 14844.025 & 295.313 & & 32 & 408 & 253.653 & & 57 & 17212.5 & 342.432 & 489.6 & 304.384 \\
\hline & 8 & 12723.450 & 253.125 & & 33 & 489.6 & 304.384 & & 58 & 14343.75 & 285.359 & 469.2 & 291.701 \\
\hline & 9 & 10602.875 & 210.938 & & 34 & 489.6 & 304.384 & & 59 & 20081.25 & 399.504 & 448.8 & 279.018 \\
\hline & 10 & 14137.167 & 281.25 & & 35 & 489.6 & 304.384 & & 60 & 43031.25 & 856.079 & 489.6 & 304.384 \\
\hline \multirow{5}{*}{$\mathrm{C} 1$} & 11 & 14137.167 & 281.25 & \multirow{5}{*}{$\mathrm{C} 2$} & 36 & 530.4 & 329.749 & \multirow{5}{*}{ C3 } & 61 & 17212.5 & 342.432 & 571.2 & 355.114 \\
\hline & 12 & 12723.450 & 253.125 & & 37 & 448.8 & 279.018 & & 62 & 22950 & 456.575 & 489.6 & 304.384 \\
\hline & 13 & 13430.309 & 267.188 & & 38 & 448.8 & 279.018 & & 63 & 25818.75 & 513.648 & 469.2 & 291.701 \\
\hline & 14 & 12723.450 & 253.125 & & 39 & 612 & 380.479 & & 64 & 25818.75 & 513.648 & 367.2 & 228.287 \\
\hline & 15 & 12016.592 & 239.063 & & 40 & 367.2 & 228.287 & & 65 & 20081.25 & 399.504 & 346.8 & 215.605 \\
\hline \multirow{5}{*}{ D1 } & 16 & 12723.450 & 253.125 & \multirow{5}{*}{ D2 } & 41 & 489.6 & 304.384 & \multirow{5}{*}{ D3 } & 66 & 22950 & 456.576 & 408 & 253.653 \\
\hline & 17 & 12723.450 & 253.125 & & 42 & 489.6 & 304.384 & & 67 & 22950 & 456.576 & 448.8 & 279.018 \\
\hline & 18 & 12723.450 & 253.125 & & 43 & 530.4 & 329.749 & & 68 & 22950 & 456.576 & 408 & 253.653 \\
\hline & 19 & 14137.167 & 281.25 & & 44 & 489.6 & 304.384 & & 69 & 28687.5 & 570.719 & 408 & 253.653 \\
\hline & 20 & 14137.167 & 281.25 & & 45 & 448.8 & 279.018 & & 70 & 25818.75 & 513.648 & 408 & 253.653 \\
\hline \multirow{5}{*}{ E1 } & 21 & 13076.879 & 260.156 & \multirow{5}{*}{ E2 } & 46 & 530.4 & 329.749 & \multirow{5}{*}{ E3 } & 71 & 28687.5 & 570.719 & 428.4 & 266.335 \\
\hline & 22 & 14137.167 & 281.25 & & 47 & 469.2 & 291.701 & & 72 & 22950 & 456.576 & 428.4 & 266.335 \\
\hline & 23 & 9189.159 & 182.813 & & 48 & 489.6 & 304.384 & & 73 & 28687.5 & 570.719 & 408 & 253.653 \\
\hline & 24 & 12016.592 & 239.063 & & 49 & 469.2 & 291.701 & & 74 & 31556.25 & 627.792 & 346.8 & 215.605 \\
\hline & 25 & 12016.592 & 239.063 & & 50 & 571.2 & 355.114 & & 75 & 28687.5 & 570.719 & 448.8 & 279.018 \\
\hline
\end{tabular}

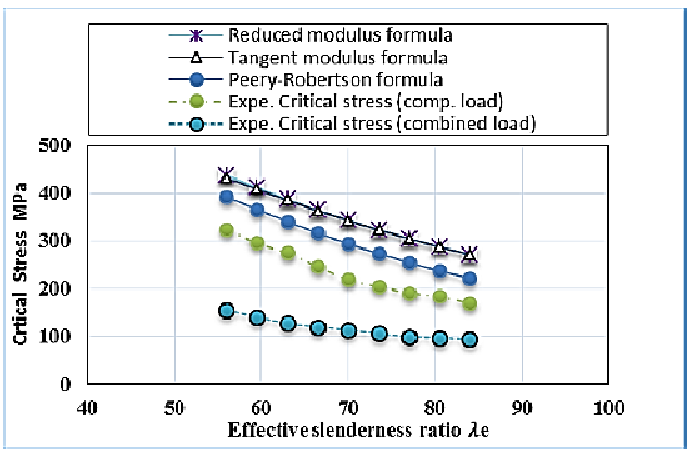

Fig. 6. Critical stress- slenderness ratio relation for stainless steel 303 AISI columns (type 1) under dynamic compression, and dynamic combined loads compared with theoretical results.

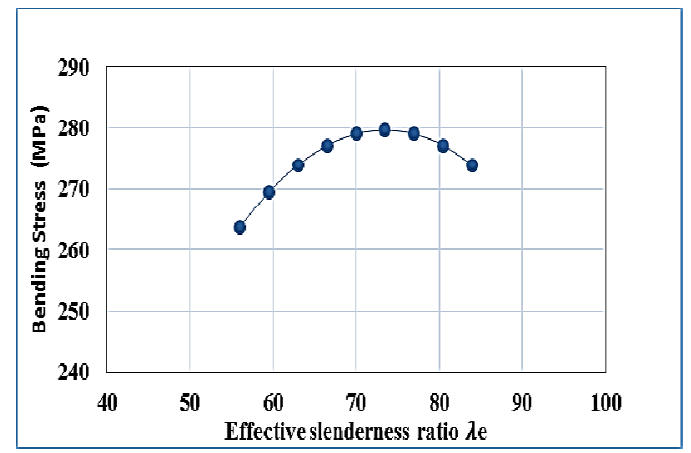

Fig. 7. Bending stress- slenderness ratio relation for stainless steel 303 AISI columns (type 1) under dynamic bending loading. 


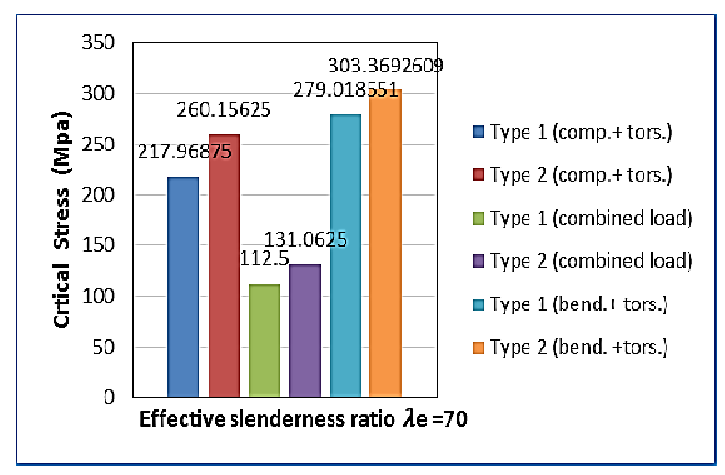

Fig. 8. Critical stress for the specimens of type (1) and type (2) at the same effective slenderness ratio.

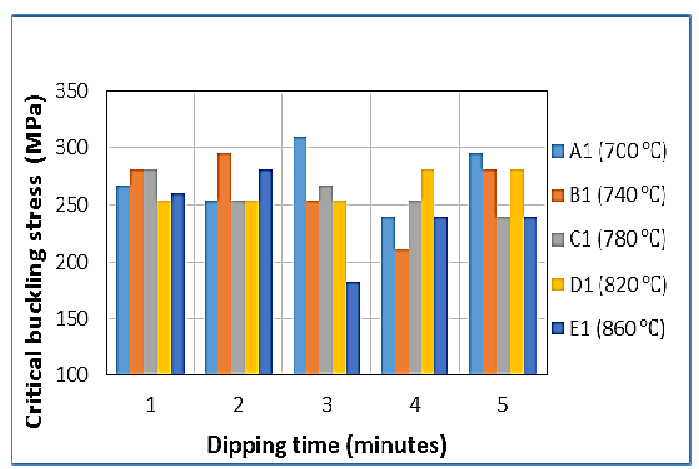

Fig. 9. Critical buckling stress- dipping time relation for HDA aluminized columns (type 2) under dynamic compression loading.

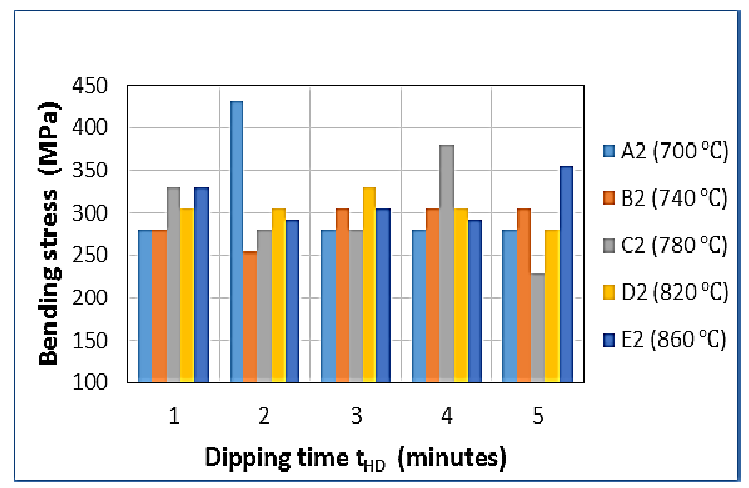

Fig. 10. Critical buckling stress- dipping time relation for HDA columns (type 2) under dynamic bending loading.
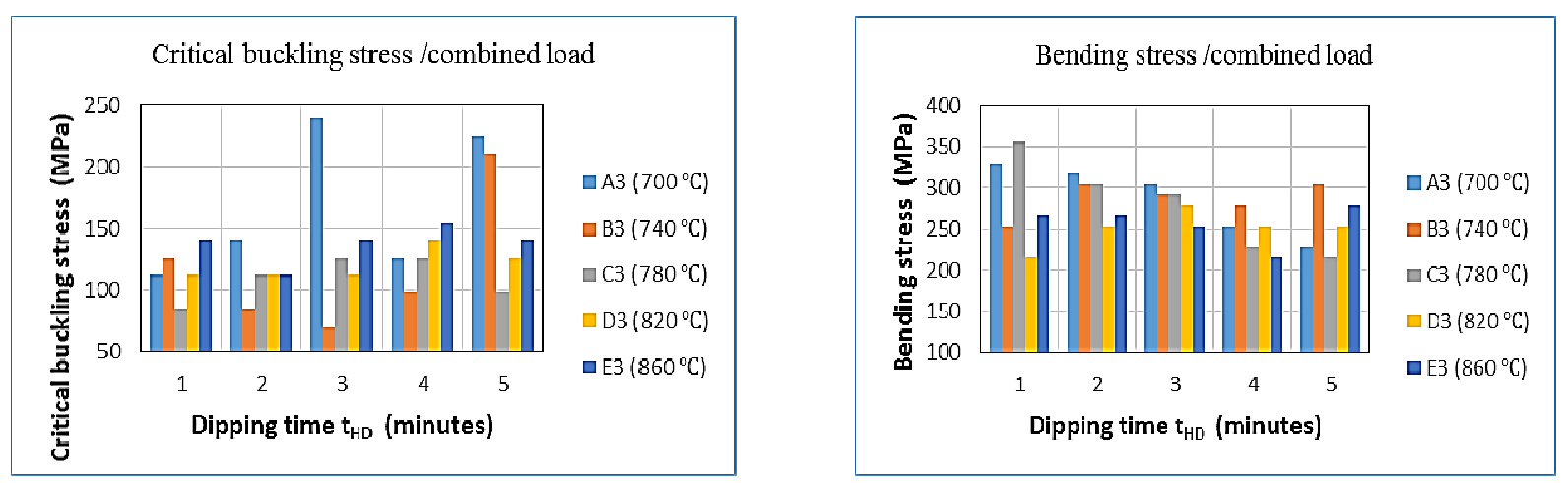

Fig. 11. Critical stress- dipping time relation for HDA columns (type 2) under dynamic combined loading. 


\section{Notation}

\begin{tabular}{|c|c|}
\hline $\boldsymbol{A}$ & $\begin{array}{l}\text { The cross-sectional area of } \\
\text { the column }\end{array}$ \\
\hline$E$ & Modulus of elasticity \\
\hline$E_{R}$ & Reduced modulus \\
\hline$E_{t}$ & Tangent modulus \\
\hline$e$ & $\begin{array}{l}\text { Critical deflection of the } \\
\text { column at a critical buckling } \\
\text { condition }=\delta_{c r}\end{array}$ \\
\hline $\begin{array}{l}F_{\text {ben }} \\
I\end{array}$ & $\begin{array}{l}\text { Experimental bending load } \\
\text { Moment of inertia of the } \\
\text { column cross sectional area } \\
\text { about z-axis }\end{array}$ \\
\hline$I_{1}$ & $\begin{array}{l}\text { Moment of inertia of the area } \\
A_{1} \text { that lies above the neutral } \\
\text { axis } n-n\end{array}$ \\
\hline$I_{2}$ & $\begin{array}{l}\text { Moment of inertia of the area } \\
A_{2} \text { that lies below the neutral } \\
\text { axis } n-n\end{array}$ \\
\hline$I_{n}$ & $\begin{array}{l}\text { Moment of inertia of the } \\
\text { column cross sectional area } \\
\text { about neutral axis n- } n\end{array}$ \\
\hline$K$ & $\begin{array}{l}\text { Effective-length factor }=0.7 \\
\text { for fixed-pinned ends support }\end{array}$ \\
\hline$L, L_{e}$ & $\begin{array}{l}\text { Unsupported and effective } \\
\text { length of the column }\end{array}$ \\
\hline $\mathrm{P}_{\mathrm{cr}} \mathrm{P}_{\mathrm{exl}}$ & $\begin{array}{l}\text { Theoretical and experimental } \\
\text { critical buckling load }\end{array}$ \\
\hline$r$ & $\begin{array}{l}\text { Smallest radius of gyration of } \\
\text { the column }\end{array}$ \\
\hline$T_{H D}$ & Dipping temperature \\
\hline$t_{H D}$ & Dipping time \\
\hline
\end{tabular}

$\mathbf{m m}^{2}$

GPa

GPa

G

$\mathbf{m m}$

$\mathbf{N}$

$\mathrm{mm}^{4}$

$\mathbf{m m}^{4}$

$\mathbf{m m}^{4}$

$\mathbf{m m}^{4}$

Dimen

sion-

less

$\mathrm{mm}$

$\mathrm{N}$

(newto

n)

mm

${ }^{\circ} \mathrm{C}$

s (sec.)

\section{Greek letters}

\begin{tabular}{|c|c|c|}
\hline $\boldsymbol{\sigma}$ & The uniaxial stress & MPa \\
\hline$\sigma_{b e n}$ & $\begin{array}{l}\text { Experimental bending } \\
\text { stress }\end{array}$ & MPa \\
\hline$\sigma_{\exp }$ & $\begin{array}{l}\text { Experimental critical } \\
\text { buckling stress }\end{array}$ & MPa \\
\hline$\sigma_{P}$ & $\begin{array}{l}\text { Theoretical Critical } \\
\text { buckling stress (Perry- } \\
\text { Robertson formula) }\end{array}$ & MPa \\
\hline$\sigma_{R}$ & $\begin{array}{l}\text { Theoretical critical } \\
\text { buckling stress (reduced } \\
\text { modulus theory) }\end{array}$ & MPa \\
\hline$\sigma_{T}$ & $\begin{array}{l}\text { Critical buckling stress } \\
\text { (tangent modulus theory) }\end{array}$ & MPa \\
\hline$\sigma_{u l t}, \sigma_{p l}$ & $\begin{array}{l}\text { Ultimate and proportional } \\
\text { limit of column's material } \\
\text { stress }\end{array}$ & MPa \\
\hline
\end{tabular}

\begin{tabular}{|c|c|c|}
\hline $\begin{array}{c}\sigma_{y} \\
\delta_{o}, \delta_{c r}\end{array}$ & $\begin{array}{l}\text { The yield strength } \\
\text { Initial and critical }\end{array}$ & $\begin{array}{l}\text { MPa } \\
\text { mm }\end{array}$ \\
\hline $\bar{\lambda}_{o}, \bar{\lambda}$ & $\begin{array}{l}\text { deflection of the column } \\
\text { The limiting and non- } \\
\text { dimensional slenderness } \\
\text { ratio }\end{array}$ & $\begin{array}{l}\text { Dimens } \\
\text { ion-less }\end{array}$ \\
\hline$\lambda_{e}, \lambda_{c}$ & $\begin{array}{l}\text { Effective and critical } \\
\text { slenderness ratio }\end{array}$ & $\begin{array}{l}\text { Dimen } \\
\text { sion- } \\
\text { less }\end{array}$ \\
\hline$\chi$ & $\begin{array}{l}\text { The reduction factor } \\
\text { accounting for buckling }\end{array}$ & $\begin{array}{l}\text { Dimen } \\
\text { sion- } \\
\text { less }\end{array}$ \\
\hline$\alpha$ & $\begin{array}{l}\text { The imperfection factor } \\
\text { (Perry-Robertson formula }\end{array}$ & $\begin{array}{l}\text { Dimen } \\
\text { sion- } \\
\text { nless }\end{array}$ \\
\hline$\varepsilon$ & The uniaxial strain & $\begin{array}{l}\text { Dimen } \\
\text { sion- } \\
\text { less }\end{array}$ \\
\hline
\end{tabular}

\section{References}

[1] T. H. G. MEGSON,"Structural and Stress Analysis", Butterworth-Heinemann, 2000.

[2] Analysis Theories, tutorials and examples", Taylor \& Francis, 2008.

[3] R. C. Hibbeler, SI conversion by S. C. Fan," Statics and Mechanics of Materials", Prentice-Hall, Inc., 2004.

[4] L. Gardner and D. A. Nethercot, "Experiments on Stainless Steel Hollow Sections-Part 2: Member Behaviour of Coloumns and Beams", Journal of Constructional Steel Research, Vol. 60, p.p. 1319-1332, (2004).

[5] Kifah Hameed Al-Jubori, "Columns Lateral Buckling Under Combined Dynamic Loading", PhD. Thesis, University of Technology, Department of Technical Education, 2005.

[6] Hamed Ali Hussein,"Buckling of Square Columns Under Cycling Loads for Nitriding Steel DIN (CK45, CK67, CK101)", PhD. Thesis, University of Technology, Department of Mechanical Engineering, 2010.

[7] Al-Alkhawi H. J. M., Al-Khazraji A. N., and Essam Zuhier Fadhel, "Determination the Optimum Shot Peening Time for Improving the Buckling Behavior of Medium Carbon Steel”, Eng. \& Tech. Journal, Vol. 32, Part (A), No. 3, 2014. 
[8] Sung-Ha Hwang, Jin-Hwa Song, and YongSuk Kim, "Effects of carbon content of carbon steel on its dissolution into a molten aluminum alloy", Materials Science and Engineering A 390, pp. 437-443, 2005.

[9] Hishamuddin Hj. Husain, Muhamad Daud, Anasyida Abu Seman and Abdul Razak Daud, "Preliminary Study on Metallic Coating of Steel Substrates through Hot Dip Aluminizing by Using Energy Dispersive XRay Spectroscopy (EDX) Technique", Journal of Nuclear and Related Technologies, Vol. 6, No. 2,pp. 63-69, December, 2009.

[10] Rajab Mohammed Hussein, "Improvement of Stainless Steel (316L) Hot Corrosion and Oxidation Resistance by AluminizingSiliconizing", PhD. Thesis, University of Technology, Department of Production Engineering and Metalluragy, 2007.

[11] G. H. Awan, F. Ahmed, L. Ali, M. S. Shuja, and F. Hasan, "Effect of CoatingThickness on the Formability of Hot Dip Aluminized Steel”, Pak. J. Engg. \& Appl. Sci., Vol. 2, p.p. 14-21, Jan 2008.

[12] N. R. Baddoo and B. A. Burgan, "Structural Design of Stainless Steel", The Steel Construction Institute, SCI Publication P291 2001, 2001.
[13] Euro Inox and The Steel Construction Institute, "Structural Design of Stainless Steel", 3rd edition, 2006.

[14] L. Gardner and D. A. Nethercot, “Designers' Guide to EN 1993-1-1. Eurocode 3: Design of Steel Structures. General Rules and Rules for Building", The Steel Construction Institute, Thomas Telford Ltd., 2005.

[15] James M. Gere, "Mechanics of Materials", 6th Ed, Thomson Learning, Inc., 2004.

[16] Zdeněk P. Bažant and Luigi Cipolin"Stability of Structures Elastic, Inelastic, Fracture, and Damage theories", Dover Puplications, Inc., 2003.

[17] ASM Handbook,"Surface Engineering", ASM International, Vol. 5, 1994.

[18] Hameed Shamkhi Jaber," The Influence of Hot-Dip Aluminizing on Buckling Behavior of Columns", PhD. Thesis, University of Technology, Department of Mechanical Engineering, 2015. 


\title{
تحسين سلوك الانبعاج الديناميكي لأعمدة الصلب المقاوم للصدأ المؤلمنة لمتوسطة الطول
}

\author{
احمد نايف الخزرجي* \\ حميد شمخي جابر الخزعلي ***ني

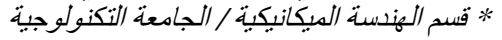

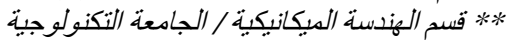

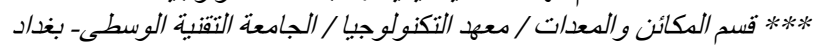

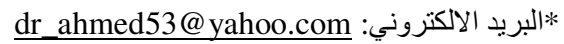 \\ alrabiee2002@yahoo.com البريد الالكتروني: الإنكي: \\ hameedshamkhi@yahoo.com البريد الالكتروني الاكروني:*****
}

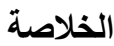

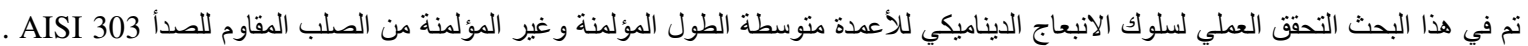

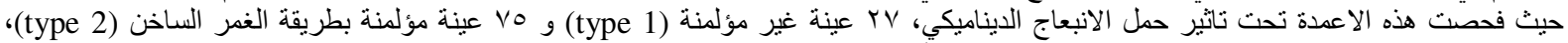

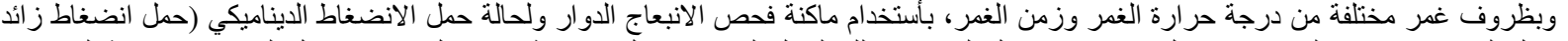

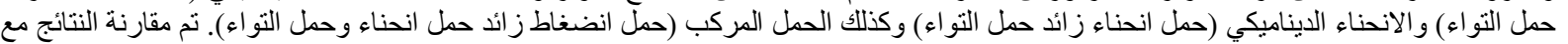

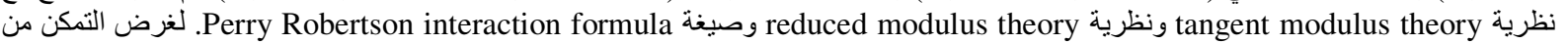

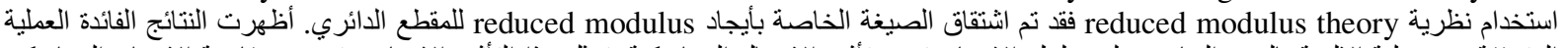

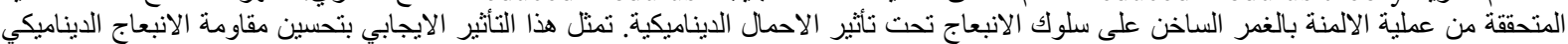

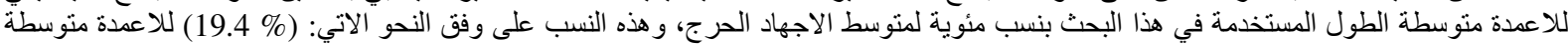

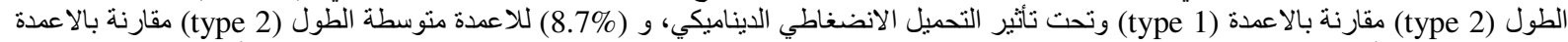

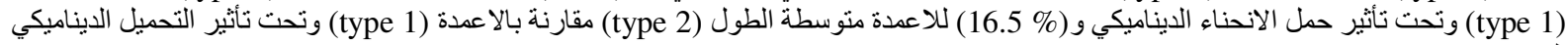


